\title{
TRANSNACIONALNI ORGANIZOVANI KRIMINAL I NACIONALNA BEZBEDNOST
}

\author{
Miloš Lakićević \\ Visoka škola strukovnih studija za kriminalistiku i bezbednost, Niš
}

\begin{abstract}
$\mathrm{D}$ ržava je svojevrsno „živo biće“ koje ima raznovrsne potrebe i može da egzistira samo ukoliko zadovoljava svoje potrebe. U tom kontekstu, država identifikuje i definiše svoje nacionalne vrednosti i čini neophodne napore da ih zaštiti i razvija. Zapravo, planski i racionalno upotrebljava nacionalnu moć s ciljem da spreči ugrožavanje njihove bezbednosti, a ukoliko je oružana ili neoružana ugrožavajuća ili samougrožavajuća delatnost proizvela izvesnu štetnu promenu na njih, da sankcioniše učinioca i otkloni nastalu štetu. Država posredstvom sistema nacionalne bezbednosti uspostavlja, održava i jača optimalno bezbednosno stanje nacionalnih vrednosti, koje, uglavnom se označava terminom nacionalna bezbednost. Na stanje nacionalne bezbednosti države povremeno ili neprekidno, direktno ili indirektno, tajno ili prikriveno, asimetrično ili simetrično i pozitivno ili negativno utiču brojni i raznovrsni uzroci, činioci i delatnosti. Reč je o kompleksu korelacija, čije dešifrovanje predstavlja konstantan zadatak upravljačkog strukturnog elementa sistema nacionalne bezbednosti države. U radu su razmotrena osnovna obeležja korelacije između transnacionalnog organizovanog kriminala i nacionalne bezbednosti.
\end{abstract}

Ključne reči: ugrožavanje, transnacionalni organizovani kriminal, korupcija, bezbednost, sistem nacionalne bezbednosti, nacionalna bezbednost

\section{Uvod}

Saka država u skladu sa ustavno-pravnom strukturom organizacije vlasti nastoji da

obezbedi zaštitu nacionalnih vrednosti od svih oblika spoljnog i unutrašnjeg ugrožavanja. U tu svrhu, sa svim državnim atributima treba da stvara demokratsko-bezbednosne uslove za provođenje vladavine zakona kao bitan preduslov obezbeđivanja opšte klime za društveno-ekonomski, socijalni, kulturni i ini razvoj građana kao pojedinaca, društvenih grupa i društva u celini. Takva njena angažovanost ukazuje na to da oblast bezbednosti predstavlja jednu od ključnih ustavnih kategorija koju, između ostalog, izražava uspostavljanjem posebne institucije, terminološki poznatija kao sistem nacionalne bezbednosti. Reč je o neophodnom, studiozno osmišljenom kulturološkom proizvodu države, hijerarhijski struktuisan od kompleksa međusobno zavisnih elemenata (podsistema) koji preduzimanjem usklađenih ofanzivno-defanzivnih preventivno-reaktivnih mera i aktivnosti konstantno štiti sistem nacionalnih vrednosti od svih vrsta ugrožavajućih delatnosti. Zamišljen (željen, planiran) rezultat sistema nacionalne bezbednosti je optimalno stanje nacionalne bezbednosti koje 
pretpostavlja pravovremeno i uspešno otklanjanje stvarnih i mogućih spoljnih i unutrašnjih opasnosti po bezbednost nacionalne teritorije, suvereniteta, fizičkog, duhovnog i imovinskog integriteta građana i drugih ustavnih vrednosti. Zapravo, nacionalna bezbednost odražava ostvarivanje trajnih nacionalnih ciljeva - opstanak i održivi razvoj matične države u prilično anarhičnoj međunarodnoj zajednici.

Problem i uzroci opstanka i budućnosti neke države mogu da budu izraz stanja unutar nje ili izvan njenih granica. Ne postoje pouzdana saznanja o tome koji od tih načina preovlađujuće utiču na urušavanje, ili potpuno uništenje država. Ipak, nije sporno da problemi (npr., bezbednosne pretnje) na unutrašnjem planu svaku državu čine nepouzdanim bezbednosnim subjektom međunarodnih odnosa. Takođe, nepravovremeno ili sporo reagovanje na postojeće izazove i pretnje, dovodi do improvizirajućim merama, što u krajnjem smislu ima za posledicu destabilizacija bezbednosti društva i države. Radi uspešnog suočavanja sa postojećim i mogućim izazovima i pretnjama, država uspostavlja sistem nacionalne bezbednosti koji treba kompleksno da odgovori na dva složena pitanja: od koga i od čega nacionalne vrednosti treba štititi? i kako ih štiti?

Bez obzira na nijansirane raznolikosti od države do države, odgovor na pitanje od koga nacionalne vrednosti treba štititi identifikuje subjekte (ljudi, kao pojedinci i ljudski kolektiviteti), čiji društveno-pravni status je suveren (državni) ili nesuveren (nevladini i transnacionalni kolektiviteti). S tim u vezi, treba imati na umu činjenicu da se u opasnosti može naći (može da bude podložna) bilo koja nacionalna vrednost, nezavisno od toga da li je izazvala (isprovocirala) subjekta opasnosti ili se opasnost ispoljava neizazvana. Po tom osnovu, nacionalne vrednosti države su podložne ugrožavanju i samougrožavanju. U prvom slučaju (ugrožavanje), spoljašni ili unutrašnji subjekt opasnosti određuje cilj i način ugrožavanja odabrane države, a ugrožavajuću delatnost - neoružanu (nesmrtonosnu), oružanu (smrtonosnu) ili kombinovanu (nesmrtonosno-smrtonosnu) može otpočeti bez objave (iznenadno, podmuklo) ili posle upućenog upozorenja ili pretnje. Reč je o smišljenom ofanzivnom činjenju, saglasnom cilju subjekta ugrožavanja. U drugom slučaju (samougrožavanje), reč je o nečinjenju, nepravovremenom, neopreznom ili neadekvatnom činjenju sistema nacionalne bezbednosti u procesu zaštite vrednosti matične države.

Krivično zakonodavstvo najvećeg broja država uzima u obzir moguće ugrožavajuće i samougrožavajuće delatnosti nacionalnih vrednosti države. Međutim, u teorijskim dokumentima iz oblasti bezbednosti (strategije) uglavnom izostaje registrovanje samougrožavajućih delatnosti, a ugrožavajuće se razvrstavaju u dve globalne grupe: oružani (vojni) izazovi, rizici i pretnje (oružana agresija, oružana intervencija, oružana pobuna i građanski rat) i neoružani (nevojni) izazovi, rizici i pretnje (špijunaža, politički i ekonomski pritisci, organizovani kriminal (podvukao autor), etnički i verski ekstremizam, terorizam, sabotaže, destruktivna propaganda i ilegalne migracije).

Organizovani kriminal je registrovan kao jednu od najsloženijih i najopasnijih pretnji za ekonomsku i socijalnu stabilnost i nacionalnu bezbednost država i konstatuje da nijedna država nije imuna na ovaj bezbednosni problem. Mnogostruki oblici ispoljavanja i rastuća ekonomska i politička moć nosilaca organizovanog kriminala potkrepljuje se ocenom o njegovom sve izraženijom infiltracijom u raznim oblastima društvenog života, a korupcija registruje kao ključno vezivno tkivo i osnovno sredstvo koje pogoduje pojavi i ekspanziji organizovanom kriminalu. $U$ tom smislu, posebno se upozorava na opasnost po nacionalnu bezbednost od prekograničnog ili transnacionalnog organizovanog kriminala. 
Organizovani (unutrašnji/lokalni i transnacionalni/globalni) kriminal preovlađujuće predstavlja ofanzivni (agresorski) oblik ugrožavanja nacionalne bezbednosti države. Međutim, ukoliko njegovi nosioci steknu veliku ekonomsku i političku moć, lukavo je koriste u smislu njegovog ispoljavanja kao samougrožavajućeg oblika nacionalne bezbednosti. U skladu sa konstatovanim, pre svega zbog kompleksnosti problema, u radu je skromno razmotrena složena međuzavisnost nacionalne bezbednosti i transnacionalnog organizovanog kriminala.

\section{Osnovne činjenice o transnacionalnom organizovanom kriminalu}

Od momenta kada je prvi put upotrebljen pojam „organizovani kriminal“ pa do danas njime je označavana protivzakonita društvena delatnost čije su održavanje i širenje prvenstveno zavisile od kriminalnog tržišta i volje vrhovnog menadžmenta određene države da se angažuje na njenom suzbijanju. Takođe, organizovanom kriminalu su bila svojstvena neka transnacionalna obeležja.

Brojni su i višestruko izukrštani objektivni i subjektivni uzroci koji utiču na pojavu i održavanju („neuništivost") organizovanog kriminala unutar jedne države, koji sistematski „probija“ njenu teritoriju omeđenu granicom. Međutim, mnoga saznanja ukazuju na njegov izvorišni uzrok - ilegalno tržište, koje nastaje i opstaje na sličnim postavkama funkcionisanja legalnog tržišta. Osnovni pokretač protivzakonitog angažovanja nosilaca organizovanog kriminala predstavlja saznanje o tome da ukoliko postoji potreba za ilegalnom robom ili uslugama na nekom prostoru (npr., određena država), neko će, rukovođen profitom, rizikovati da zadovolji potrebe zainteresovanih. Reč je organizovanoj ilegalnoj delatnosti između čijih aktera (učinioca i neposredne žrtve) preovlađuje odnos na dobrovoljnoj osnovi: krajnji korisnik (žrtva) pokazuje interesovanje za ponuđenu robu i spremnost da zaštiti dobavljača (učinioca krivičnog dela) i da pronalazi nove žrtve (npr., uživalac opojnih droga). Dakle, funkcionisanje kriminalnog tržišta se bitno ne razlikuje od funkcionisanja legalnog tržišta, iako se radi o tržištu robe i usluga čiji je promet strogo zabranjen i kontrolisan od strane državnih institucija. ${ }^{2} U$ literaturi su u opticaju različiti modeli kriminalnog tržišta, ${ }^{3}$ koje najčešće obuhvata: nelegalne robe (opojne droge, oružje, falsifikovan novac...), nelegalnu trgovinu legalnim robama (izbegavanje plaćanja poreza) i nelegalno pružanje usluga (krijumčarenje ljudi, prostitucija). ${ }^{4}$

\footnotetext{
${ }^{1}$ Upotrebljen je početkom 18. veka za označavanje protivzakonitih delatnosti jedne kriminalne bande u Engleskoj predvođenom Jonathan-om Wild-om, koji je imao zaštitu tadašnjeg engleskog kralia George-a I. Krađe koje su vršili pripadnic te bande bile su bitno drugačije od krađa drugih bandi, jer je ukradene stvari vođa (Jonathan Wild) „pronalazio“ i vraćao vlasnicima uz pozamašnu novčanu nagradu. Ukoliko je vlasnik ukradenih stvari odbio da ih povrati, vođa bande ih je prodavao preko svoje mreže u Engleskoj, Francuskoj, Holandiji i Belgiji. Vođa te bande je posle smrti engleskog kralja optužen i obešen 24. maja 1725. godine. - Shmalleger, F.: Criminology Today, Englewood Cliffs, London, 1996, p. 348.

${ }^{2}$ Bošković, G.: „Organizacija i funkcionisanje kriminalnog tržišta“, Revija za bezbednost, Centar za bezbednosne studije, Beograd, 8, 2008, str. 40

${ }^{3}$ Naylor T. R.: „A critique of follow-the-money methods in crime control policy“, Crime, Law and Social, Vol 32, London, 1999, p. 25.

${ }^{4}$ Prema prvom modelu, organizacija kriminalnog tržišta počiva na principu apsolutnog monopola (moć je koncentrisana na vrhu hijerarhijske piramide, gde se odlučuje o preraspodeli profita, cenama robe, strategiji i sl.); drugi model počiva na principu poverenja (više nezavisnih kriminalnih kolektiviteta su se saglasili da delegiraju svoje predstavnike u „centralni organ“ koji donosi odluke o...); treći model je zasnovan na principu decentraliza-
} 
Modeli kriminalnog tržišta nagoveštavaju organizovanost i vrste delatnosti organizovanih kriminalnih kolektiviteta, koje načelno, svode se na (1) organizovane kriminalne kolektivitete striktno zasnovanih na lokalnom teritorijalnom principu (na teritoriji jedne države) koji ne sprovode prekogranične (transnacionalne) aktivnosti i (2) organizovane kriminalne kolektivitete, etnički homogene ili multietnički, organizovanih na teritoriji jedne ili više država, koji sprovode i transnacionalne aktivnosti.

Nesumnjiv je uticaj objektivnih uzroka na pojavu organizovanog kriminala i funkcionisanje kriminalnog tržišta. Međutim, vrlo važno je imati na umu činjenicu o tome da subjektivni uzroci imaju presudan uticaj na ispoljavanje i zamah ili eskalaciju organizovanog kriminala u nekoj državi. To potvrđuju relevantna saznanja o direktnom ili indirektnom učešću službenih lica (koruptivnih pripadnika iz državne administracije) u organizovanom kriminalu. Naime, pripadnici (privatna lica) organizovanih kriminalnih kolektiviteta svesni su da njihovo protivzakonito delovanje (vršenje krivičnih dela - snabdevanje tržišta zabranjenom robom) radi sticanja imovinske koristi, bez učešća službenih lica u tom procesu, može da bude samo privremeno uspešno. Zapravo, može da traje samo onoliko koliko je vlastima potrebno vreme da otkriju i onemoguće njihovo društveno opasno delovanje. Zato, njihova je konstantna zaokupljenost pitanjem (problemom) kako da za svoje protivzakonito delovanje pridobiju i uključe službena lica. Svaki postignuti uspeh (infiltracija) u nekoj državnoj instituciji (npr., korumpiran predsednik opštine, policajac, sudija, carinik itd. $)^{5}$ oni nastoje da povećaju do nivoa koji im obezbeđuje adekvatan imunitet kriminalnog delovanja na određenoj teritoriji ili u jednoj oblasti društvenog života. Tako uspostavljena kriminalna sprega privatnih i službenih lica omogućava organizovanim kriminalcima nesmetanu delatnost u određenoj oblasti i garantuje odgovarajuću zaštitu od otkrivanja i sankcionisanja. U krajnjem, stvara povoljne uslove da „operu prljavi novac“ i ulože ga u legalni biznis (na legalnom tržištu), dakle urušavaju ekonomsku osnovicu društva i države. Ovim postaje jasno zašto organizovani kriminal predstavlja izražena pretnja nacionalnoj bezbednosti države.

Akademsko i pravno određenje organizovanog kriminala uzima u obzir opasnost po nacionalnu bezbednost od organizovano kriminalnih kolektiviteta, posebno od onih koji su izvršili prodor u sistemu političke vlasti države. Akademski autoriteti, uspostavljenu spregu između privatnih i službenih lica kvalifikuju u smislu da organizovani kriminal je „trajna organizacija, organizacija koja racionalno radi zbog profita, korišćenje sile ili pretnji, $i$ potreba za korupcijom da bi se očuvao imunitet od primene prava"; ", "oblici organizovanog kriminala su delovanja kod kojih su uspostavljene veze između šefova kriminalnih organizacija i pojedinaca iz strukture državnih vlasti"; ", "organizovani kriminal ... mora konzumirati još neka obeležja, od kojih se kao najspecifičnija ističe veza sa nosiocima državne vlasti ${ }^{i 8}$ itd.

cije (postojanje više nezavisnih kriminalnih kolektiviteta koji objedinjavaju svoju moć u slučajevima ugroženosti zajedničkih interesa na kriminalnom tržištu) i četvrti model, koji odražava kriminalno tržište kao skup nezavisnih kolektiviteta, koji objedinjavaju zajednički interesi (skup podeljenih manjih tržišta u zavisnosti od robe koja se nudi na njemu). Weenink W. A.: Crime without frontiers: Crime Pattern Analysis Eastern Europe, 2002-2003, Neatherlands: Korps Landelijke Politienstern, Driebergen, 2004, p. 32.

${ }^{5}$ Pripadnici Ministarstva unutrašnjih poslova Uprave kriminalističke policije zaplenili su oko tri kilograma heroina i uhapsili četiri osobe, među kojima i policajca, saopštio je 20. maja 2018, MUP Srbije. - N. N.: „Zaplenjen heroin, među uhapšenima i policajac", Politika, Beograd, 21. 5. 2018, str. 5.

${ }^{6}$ Albanese, S. J.: „The causes of organized crime“, Journal of Contemporary Criminal Justice, Thousand Oaks, No. 4, 2000, pp. 412.

${ }^{7}$ Bošković, M.: Transnacionalni organizovani kriminalitet, Policijska akademija, Beograd, 2003, str. 7.

${ }^{8}$ Marinković, D.: „Organizovani kriminalitet - izazov krivičnom zakonodavstvu“, Bezbednost, MUP Srbije, Beograd, 2, 2004, str. 194. 
Suština pravnog određenja organizovanog kriminala je u vezi sa rečjom „organizovani“, koja ovu vrstu društveno štetnog i protivpravnog ponašanja kvalifikuje kao dogovorno vršenje teških krivičnih dela najmanje tri lica, odnosno evidentan je institut saučesništva, koji pretpostavlja još neka obeležja. Organizovani kriminal u pozitivnom zakonodavstvu Republike Srbije predstavlja vršenje krivičnih dela od strane organizovane kriminalne grupe ili njenih pripadnika, a pod organizovanom kriminalnom grupom podrazumeva se grupa od tri ili više lica koja postoji određeno vreme i deluje sporazumno u cilju vršenja jednog ili više krivičnih dela za koje je propisana kazna zatvora od četiri godine ili teža kazna, radi sticanja, posredno ili neposredno, finansijske i druge koristi. ${ }^{9}$ Operacionalizovanost ove definicije u Zakonu o krivičnom postupku Republike Srbije (član 21), iz 2005. godine ukazuje da organizovani kriminal obuhvata slučajeve postojanja osnovane sumnje da je krivično delo rezultat delovanja tri ili više lica udruženih u kriminalnu grupu (kriminalni kolektivitet) koja vrši krivična dela radi sticanja dobiti ili moći, kada su, pored toga, ispunjena najmanje još tri od sledećih uslova: da je svaki član kriminalnog kolektiviteta imao unapred određeni, odnosno očigledno odredivi zadatak ili ulogu; da je delatnost kriminalnog kolektiviteta planirana na duže vreme ili za neograničeni vremenski period; da se delatnost kriminalnog kolektiviteta zasniva na primeni određenih pravila unutrašnje kontrole i discipline članova; da se delatnost kriminalnog kolektiviteta planira i vrši u međunarodnim razmerama (podvukao autor); da se u vršenju delatnosti primenjuju nasilje ili zastrašivanje ili da postoji spremnost za njihovu primenu; da se u vršenju delatnosti koriste privredne ili poslovne strukture; da se koristi pranje novca ili nezakonito stečene dobiti; i da postoji uticaj kriminalnog kolektiviteta ili njenog dela na političku vlast, sredstva javnog informisanja, zakonodavnu, izvršnu ili sudsku vlast ili na druge važne društvene ili ekonomske činioce.

Jedan od pomenutih uslova u pozitivnom zakonodavstvu Srbije (da se delatnost kriminalnog kolektiviteta planira i vrši u međunarodnim razmerama) ukazuje na njegovu moguću transnacionalnost. Prvenstveno uzimanjem u obzir to obeležje, OUN je definisala organizovani kriminal ${ }^{10}$ kao organizovanu kriminalnu grupu koju čine tri i više lica, koja postoji određeno vreme i deluje sporazumno s ciljem vršenja jednog ili više teških krivičnih dela radi sticanja posredno ili neposredno, finansijske ili druge materijalne koristi. ${ }^{11}$ Termin "transnacionalni“'12 organizovani kriminal je u stavu 3. stav 2. Konvencije određen na sledeći način: ako je delo počinjeno u više država; ako je delo počinjeno u jednoj dr-

9 „Zakon o organizaciji nadležnosti državnih organa u suzbijanju organizovanog kriminala“, Službeni glasnik $R S$, br. 42/2002, 27/2003, 39/2003, 67/2003, 29/2004, 45/2005, 61/2005, 72/2009; „Zakon o krivičnom postupku“, Službeni list SRJ, br. 70/2001 i Službeni glasnik RS, br. 58/2004, 85/2005, 115/2005; „Krivični zakonik Republike Srbije“, Službeni glasnik RS, br. 58/2004, 85/2005, 88/2005 i 107/2005.

${ }^{10}$ Kancelarija za droge i zločine OUN u novembru 2000. godine na konferenciji u Palermu (Italija) usvojila je sledeće pravne akte: Konvencija protiv transnacionalnog organizovanog kriminala i njoj pratećih protokola Protokol protiv krijumčarenja migranata kopnom, morem i vazduhom, Protokol za prevenciju, suzbijanje i kažnjavanje trgovine ljudima, posebno ženama i decom i Protokol protiv ilegalne proizvodnje i trgovine vatrenim oružjem, delovima, komponentama i municijom.

${ }^{11}$ „Konvencija Organizacije ujedinjenih nacija protiv transnacionalnog organizovanog kriminala“, Službeni list SRJ - Međunarodni ugovor, broj 6/2001, str. 20.

${ }^{12} \mathrm{U}$ opštem smislu, pojam „transnacionalni“ podrazumeva profitne ili neprofitne ljudske odnose koje prelaze granice nacionalnih država. Reč je o transnacionalnom legalnom ili ilegalnom kolektivitetu koji čine državljani najmanje dve države, koji je konstituisan bez posredovanja (angažovanja) vlada njihovih matičnih država. 
žavi, ali je suštinski deo njegovog pripremanja, planiranja, organizovanja i rukovođenja izvršeno u drugoj državi; ukoliko je počinjeno na teritoriji jedne države, ali je počinjeno od organizovane kriminalne grupe (kolektiviteta) koja je uključena u kriminalne aktivnosti u više od jedne države; ukoliko je počinjeno u jednoj, ali ima efekte i na drugu(-e) države. Ovakvo definisanje je osnaženo protokolima koji su pridodati Konvenciji, kojima se poseban naglasak stavlja na borbu protiv krijumčarenja ljudima, trgovine ženama i decom i ilegalne proizvodnje i trgovine oružjem.

Transnacionalni organizovanog kriminala u Konvenciji uslovno je razvrstan u četiri posebne celine: kriminalizacija učešća u organizovanoj kriminalnoj grupi, kriminalizacija „pranja" dobiti stečene vršenjem krivičnih dela, kriminalizacija korupcije i kriminalizacija opstrukcije pravosuđa. Međutim, nijedna od pomenutih celina ne daje definiciju organizovanog kriminala, već ga definiše preko određenja organizovane kriminalne grupe (tri ili više lica, čije se postojanje proteže kroz određeni vremenski period i deluje organizovano radi izvršenja jednog ili više teških krivičnih dela sa ciljem ostvarenja, direktno ili indirektno, finansijske ili druge materijalne koristi) i putem teškog krivičnog dela (težak zločin koji je kažnjiv kaznom lišenja slobode od minimum četiri godine zatvora ili nekom težom kaznom).

Konvencija protiv transnacionalnog organizovanog kriminala preporučuje državama osnovne oblasti u kojima je potrebno ujednačavanje shvatanja o tome koja krivična dela potpadaju pod transnacionalni organizovani kriminal, izgradnju mehanizama saradnje između država u vidu ekstradicije i razmene informacija, zaštitu svedoka i prevenciju organizovanog kriminala. Centralna odrednica u Konvenciji predstavlja saradnja između država u preduzimanju konkretnih radnji radi sprečavanja i suzbijanja organizovanog kriminala. U tom kontekstu, poseban značaj ima član 12. Konvencije koji preporučuje konfiskaciju i zaplena imovine stečene vršenjem krivičnih dela koja potpadaju pod organizovani kriminal.

Raspoloživa saznanja ukazuju na to da savremeni organizovani kriminal unutar granica jedne države često se preliva preko njenih granica, odnosno povremeno ili sistematski dobija transnacionalne dimenzije. Naime, potreba za ilegalnom robom ili uslugama i nečija protivzakonita angažovanost da zadovolji potrebe zainteresovanih (kriminalno tržište) dovodi do uspostavljanja raznih oblika saradnje između organizovanih kriminalnih kolektiviteta iz jedne države s organizovanim kriminalnim kolektivitetima u drugoj(-im) državi(-ama), kao i konstituisanje autonomnih transnacionalnih organizovanih kriminalnih kolektiviteta. Opšta svrha njihovog kriminalnog delovanja - teška krivična dela radi: a) neposrednog ili posrednog sticanja finansijske i druge koristi ili b) ostvarivanja ili zadržavanja uticaja na privredne ili druge važne državne strukture, dakle, sprega s koruptivnim pojedincima ili grupama državnih organa, koja se ispoljava aktivnim odnosom (saučesništvo, saradnja, pomoć, podrška) ili pasivnim odnosom (obezbeđivanje imuniteta od sankcija - nepokretanje istraga, izbegavanje ili sabotiranje sudskih postupaka...) ima za posledicu nanošenje ogromne štete pojedincima, društvu i državi (naglo protivzakonito bogaćenje manjine i siromašenje većine stanovništva, erozija morala i sistema nacionalnih vrednosti, prisutnost „neideološkog“ nasilja i izgledno političko nasilje, naročito terorističko). Zato, transnacionalni organizovani kriminal predstavlja jednu od najopasnijih nekonvencionalnih pretnji velikom broju država savremenog sveta, odnosno njegovi nosioci su neprijatelj koji država mora pobediti da je oni ne bi „zarobili“. Organizaciona, tehnološka, prostorna i vremenska kompleksnost transnacionalnog organizovanog kriminala, između ostalog, legitimišu ga kao ugrožavajući činioc koji nastoji da svoj opstanak i svoju 
zaštitu obezbedi primenom sile ili zastrašivanjem, prioritetno korišćenjem uspostavljenih pozicija u državnim institucijama. Upravo zato, transnacionalni organizovani kriminal predstavlja teško otklonjiva pretnja nacionalnoj bezbednosti države.

\section{Osnovne činjenice o nacionalnoj bezbednosti}

Za sintagmatski pojam nacionalna bezbednost u literaturi postoje brojne definicije, čiji sadržaj uglavnom obuhvata ključne elemente pojma bezbednost (objekt bezbednosti, subjekt bezbednosti i subjekt opasnosti) i naravno, specifična međuzavisnost pomenutih elemenata. Zato, za valjano razumevanje pojma nacionalna bezbednost, uputno je poći od odgovora na glavnu liniju pitanja koje dešifruju pojam bezbednost: „šta se štiti - ko štiti - od koga se štiti?"13 Štite se vrednosti koje odražavaju identitet i obezbeđuju opstanak i razvoj određenog ljudskog kolektiviteta (subjekt bezbednosti), terminološki poznatije kao objekt bezbednosti. Vrednosti štiti fizičko ili pravno lice (subjekt bezbednosti), čiji društveno-pravni status može biti nesuveren ili suveren. On štiti sopstvene vrednosti od opasnosti (ugrožavanja) koje prete da uruše, unište ili otmu njegove vrednosti. Zapravo, štiti ih od nosilaca ugrožavajućih delatnosti (subjekt opasnosti) i od izvora (prirodnih sila - poplava, zemljotres...).

U skladu sa konstatovanim, naravno i činjenice da država je referentni objekt $i$ subjekt bezbednosti međunarodne zajednice, koja opstaje i razvija se u anarhičnom međunarodnom sistemu (odsustvo vrhunskog kredibilnog autoriteta), čija važna odlika predstavlja nepoverenje među državama, predstavljaju kvalitetan okvir za utvrđivanje značenja pojma nacionalna bezbednost. Naime, opasnost po bezbednosti vitalnih vrednosti određene države prvenstveno dolazi od težnje drugih država da uvećaju sopstvenu moć i bezbednost, između ostalog, i agresivnim namerama i postupcima prema vrednostima drugih država. ${ }^{14}$ Ukoliko vrhovni menadžment određene države ispolji neopreznost ili nesposobnost u procesu osnaživanja njene moći i bezbednosti, u nekakvoj meri rizikuje samougrožavanje $i$ ugrožavanje nacionalnih vrednosti, uključujući i mogućnost ugrožavanja njenog opstanka i održivog razvoja.

Objekt bezbednosti (nacionalne vrednosti) predstavlja sintezu poželjnog mnoštva različitih subjekata države (stanovništva) i izražavaju životne potrebe građana, društva i države. To znači da svaki oblik urušavanja ili uništenja može ugroziti biće države. Zato se ove vrednosti terminološki označavaju kao vitalne državne vrednosti, a formulisane su u najvišem državnom aktu - ustavu. Ovde spadaju prava, slobode i obaveze građana, suverenitet (politička nezavisnost), teritorijalni integritet i društveno uređenje, odnosno državna vlast.

Analogno tome, država (subjekt bezbednosti) nastoji da odsudno štiti (brani) svoje nacionalne vrednosti, upotrebom celokupne nacionalne moći, odnosno primenom adekvatnih strategija i sredstava. U tu svrhu, država uspostavlja makrobezbednosni sistem (sistem nacionalne bezbednosti), koji sačinjavaju brojni višenivovski mikrobezbednosni

\footnotetext{
${ }^{13}$ Mijalkovski, M.: Obaveštajne i bezbednosne službe, Univerzitet u Beogradu - Fakultet bezbednosti, Službeni glasnik, Beograd, 2099, str. 18.

${ }^{14}$ Anarhija u međunarodnom sistemu može imati direktan uticaj na izbijanje ratova kroz delovanje „dileme bezbednosti“, pri čemu mere koje jedna država donosi za povećanje svoje bezbednosti predstavljaju pretnju drugim državama koje, kao rezultat, preduzimaju odbrambene korake što, zauzvrat, smanjuje osećaj bezbednosti prve države. - Miller, B.: Security: Should it be Redefined? In bar-Joseph,U. (ed) (2001). Izrael's National Security Towards the 21st Century, Frank Cass, London, 2001, p. 15.
} 
sistemi. Procena sopstvenih bezbednosnih mogućnosti radi optimalne zaštite nacionalnih vrednosti od ugrožavajućih delatnosti ma od koga dolazile - subjekta opasnosti ili sopstvenih subjektivnih slabosti, predstavlja osnovno obeležje funkcionisanja sistema nacionalne bezbednosti države. Bez obzira na specifičnosti bezbednosne procene svake države ponaosob, pregled sadržaja tzv. „krovnog“ dokumenta (strategija nacionalne bezbednosti) ukazuje na to da preovlađuje broj država savremenog sveta koje ugrožavajuće delatnosti usmerenih prema sopstvenim vitalnim vrednostima, pre svega, klasifikuju prema kriterijumu prostora (spoljne i unutrašnje) i kriterijumu mogućih fizičkih posledica (oružane/vojne/smrtonosne i neoružane/nevojne/nesmrtonosne).

Načelno, sistem nacionalne bezbednosti države kao nosioce spoljnih ugrožavajućih delatnosti registruje suverene (država, savez država, grupa država, međunarodne organizacije) i nesuverene (legalne i ilegalne, profitne i neprofitne) subjekte, a kao unutrašnje nosioce ugrožavajućih delatnosti registruje: pojedince i kolektivitete (grupe, udruženja, organizacije, pokrete...). Za svakog nosioca (subjekt opasnosti) ugrožavajućih delatnosti usmerenih prema nacionalnim vrednostima matične države, utvrđuje i sledeće činjenice: karakter cilja - ograničen (omalovažavanje ili destabilizovanje nacionalnih vrednosti) ili radikalan (preoblikovanje, uništenje ili otimanje nacionalnih vrednosti); da li predstavlja bezbednosni izazov (postoji mogućnost, ali ne mora da preduzme ugrožavajuću delatnost) ili bezbednosna pretnja (sprovodi određenu neoružanu ili oružanu delatnost ili preti njenim preduzimanjem); da li prikriveno (tajno) ili javno preduzima ugrožavajuću delatnost, da li ugrožavajućom delatnošću direktno ili indirektno deluje na nacionalne vrednosti i učestalost ugrožavajuće delatnosti (na mah, povremeno, kampanjski ili neprekidno).

Svaka država u svom tzv. krovnom terorijskom dokumentu iz oblasti bezbednosti (strategija nacionalne bezbednosti) registruje oblike ugrožavanja nacionalnih vrednosti (terminološki ih označavaju kao izazovi, rizici i pretnje nacionalnoj bezbednosti ili nekonvencionalne i konvencionalne $)^{15}$ i naravno, način njihove optimalne zaštite.

Osnovna svrha pomenute (procenske) angažovanosti sistema nacionalne bezbednosti države jeste da planira, organizuje i preduzima mere i aktivnosti radi optimalne zaštite nacionalnih vrednosti od svih oblika njihovog ugrožavanja. Reč je o stanju nacionalnih vrednosti koje odražava odsustvo opasnosti (niko im ne predstavlja pretnju) ili prisustvo opasnosti (postoje pretnje, ali država ih uspešno otklanja - odvraća, sprečava i suzbija), odnosno pokazuje sposobnost da zaštiti nacionalne vrednosti od postojećih (aktuelnih) i mogućih (potencijalnih) pretnji. U tom kontekstu, nacionalnu bezbednost definišu domaći i strani autoriteti, ${ }^{16}$ poput: „odsustvo ili bar takvu prirodu i nivo pretnje po opstanak i neza-

\footnotetext{
${ }^{15}$ U Strategiji nacionalne bezbednosti Republike Srbije (Službeni glasnik RS, br. 88/2009), konstatovano je da „osnovna pretnja bezbednosti Republike Srbije jeste pokušaj otcepljenja teritorije Autonomne pokrajine Kosovo i Metohija“. Osim nje, navode se još sledeći izazovi, rizici i pretnje nacionalnoj bezbednosti: opasnost od oružane agresije, separatističke težnje, protivpravno jednostrano proglašena nezavisnost Kosova, oružana pobuna, terorizam, proliferacija oružja za masovno uništenje, nacionalni i verski ekstremizam, obaveštajna delatnost, organizovani kriminal, korupcija, problemi ekonomskog razvoja, energetska međuzavisnost, neravnomeran privredni i demografski razvoj, nerešen status i težak položaj izbeglih, prognanih i interno raseljenih lica, nedovršen proces razgraničenja između država nekadašnje SFRJ, nekontrolisano trošenje prirodnih resursa i ugrožavanje životne sredine, posledice elementarnih nepogoda... narkomanija, destruktivno delovanje pojedinih verskih sekti i kultova i dr.

${ }^{16}$ Opširnije u: Bajagić, M.: Međunarodna bezbednost, Kriminalističko-policijska akademija, Beograd, 2012, str. 203-209.
} 
visnost nacije-države, koji omogućavaju da se sopstvenim i, eventualno, savezničkim i drugim sredstvima (kolektivne bezbednosti) one otklone i, s tim u vezi, odsustvo straha, odnosno osećanje spokojstva“; ${ }^{17}$ „nacionalna bezbednost je sloboda od straha, pretnji i fizičkog nasilja nad stanovništvom, odnosno građanima jedne države“; ${ }^{18}$ "nacionalna bezbednost podrazumeva zaštitu osnovnih vrednosti države, odnosno usaglašenih interesa bez obzira na troškove koji mogu nastati“; ${ }^{19}$ „pod nacionalnom bezbednošću se obično smatra odsustvo pretnji najvažnijim vrednostima“"20 itd.

Uvažavanjem razmotrenih činjenica, u sažetom smislu, pod nacionalnom bezbednošću možemo podrazumevati stanje nacionalnih vrednosti bez opasnosti i efikasno otklanjanje opasnosti (optimalna zaštićenost nacionalnih vrednosti), koje je rezultat složenog, realističnog i dinamičnog nacionalnog programa (normativna regulativa, institucionalna organizovanost i odsudna operativna angažovanost) države u objektivnoj (prirodnoj i društvenoj) sredini koju karakteriše neizvesnost. Reč je zapravo o sposobnosti države da definiše, promoviše i održava svoje subjektivno htenje (ciljeve i interese) u skladu sa objektivnim uslovima, odnosno da proizvodi promene (utiče na objektivne činioce i trpi njihov uticaj) koje obezbeđuju njen opstanak i održivi razvoj.

\section{Korelacija između nacionalne bezbednosti i transnacionalnog organizovanog kriminala}

Ostvarivanje trajnih nacionalnih ciljeva države (opstanak i održivi razvoj) zavisi od kompleksa objektivnih i subjektivnih društveno-političkih uslova, uzroka i činilaca. Zapravo, sudbina određene države neizostavno zavisi od količine moći koju ima i naročito od načina njenog racionalnog ili iracionalnog korišćenja. Racionalno korišćenje moći uglavnom obezbeđuje uspešnu odbranu nacionalnih vrednosti u određenom trenutku i budućnosti, dok iracionalno trošenje moći stvara privid o uspešnom ostvarivanju trajnih nacionalnih ciljeva. Odluku o korišćenju nacionalne moći donosi vrhovni menadžment države, a važan preduslov tome predstavlja valjana identifikacija oblika ugrožavanja bezbednosti nacionalnih vrednosti, njihovo razvrstavanje u grupe i podgrupe. U tom smislu, posebno je važno „ustanovljavanje najopasnijeg oblika ugrožavanja bezbednosti određene države u datom trenutku“. ${ }^{21}$ To, pre svega, zato što takvo saznanje treba da utiče na određivanju težišta angažovanja sistema nacionalne bezbednosti. U suprotnom, postoji mogućnost (opasnost) da bezbednosni resursi države nemaju odbrambeno težište u svom angažovanju, odnosno proporcionalno se „troše" na sprečavanju i suzbijanju svih delatnosti

\footnotetext{
${ }^{17}$ Miletić, A.: Nacionalni interes $u$ američkoj teoriji međunarodnih odnosa, Savremena administracija, Beograd, 1978, str. 19.

${ }^{18}$ Gaćinović, R.: „Klasifikacija bezbednosti“, Nauka, bezbednost, policija, Kriminalističko-policijska akademija, Beograd, 2, 2012, str. 11.

${ }^{19}$ Leffler, M. P.: "National Security", Journal of American History, 1990, No. 77, p. 145; in Baldwin, D.: "The Cocept of Security", Review of International Security, Vol. 23, No. 1, 1997, p. 16

${ }^{20}$ Ney, J. S.: Understanding International Conflicts (5th edition), Pearson Education, New York, 2005, p. 222.

${ }^{21}$ Mijalkovski, M.: „Organizovani kriminal - najopasniji oblik ugrožavanja bezbednosti države“, Revija za bezbednost, Centar za bezbednosne studije, Beograd, 12, 2008, str. 6.
} 
usmerenih na urušavanje nacionalnih vrednosti matične države. U tom slučaju, najopasnija ugrožavajuća delatnost ima neverovatnu pogodnost i prednost za ispoljavanje u odnosu na druge ugrožavajuće delatnosti.

Saznanja o uzrocima, ekspanziji, ofanzivnosti, rasprostranjenosti, organizovanosti, „,nenasilnim" ispoljavanjem i oblicima nasilja i zastrašivanja, korišćenju svih oblika globalnih, ekonomskih i tehnoloških procesa, vrednostima napada i višedimenzionalnim štetnim posledicama transnacionalnog organizovanog kriminala za najvećeg broja državu savremenog sveta ukazuju na potrebu da bude registrovan kao najopasnija spoljno-unutrašnja nekonvencionalna pretnja nacionalnoj bezbednosti državi. S tim u vezi, važno je imati u vidu da unutrašnji organizovani kriminal (posebno korupciju) ne može ni jedno društvo (država) iskoreniti u potpunosti (to ne uspevaju ni države sa dugom demokratskom tradicijom). Takođe, treba imati u vidu da transnacionalni organizovani kriminalni kolektiviteti uspevaju da ostvaruju raznovrsna savezništva sa organizovanim kriminalnim kolektivitetima unutar ciljane države. Nezavisno od karaktera njihove međusobne sprege, relevantne činjenice ukazuju na to da odbrana od te prekogranične pretnje ne može se uspešno ostvarivati samo na nacionalnom nivou. I međunarodna zajednica je uočila dotično ograničenje i reagovala donošenjem niza međunarodnih akata radi unapređenja saradnje između država u borbi protiv transnacionalnog organizovanog kriminala. Uprkos tome, u opticaju je privid o enigmatskoj korelaciji između nacionalne bezbednosti država i transnacionalnog organizovanog kriminala. U suštini, pre svega, radi se o odsustvu volje vrhovnog menadžmenta država da odsudno štiti nacionalne vrednosti od transnacionalnog organizovanog kriminala, ${ }^{22}$ time, doprinoseći i urušavanju međunarodne bezbednosti. Izvorište te anomalije je političkoj korupciji koja se razlikuje od „obične“ ili „klasične“ korupcije po tome što su usluge kojima se trguje političke prirode: „političke funkcije, trgovina glasovima i poslanicama u parlamentu, i tome slično“, ${ }^{23}$ a njeni počinioci (ljudi na političkim funkcijama) nanose štetu matičnoj državi koja je veća od bilo kog oblika organizovanog kriminala. Inače, uputan način za otklanjanje dotične dileme jeste obuhvat (objašnjenje) karakterističnih obeležja uzajamnog uticaja između nacionalne bezbednosti i transnacionalnog organizovanog kriminala. „Beskonačan" broj ugrožavajućih delatnosti transnacionalnih organizovanih kolektiviteta (svaka oblast društvenog života podložna je organizovanom kriminalu, a da li će neka od njih postati kriminalno tržište ne zavisi od ciljeva i angažovanje njegovih nosilaca, već od protivkriminalne volje vrhovnog menadžmenta države), nameće potrebu da za (deskriptivno-objašnjavajući) obuhvat problema treba uzeti u obzir jednu od najfrekfentnijih delatnosti: narkokriminal, krijumčarenje i trgovina ljudima, korupcija i pranje novca $i$ isprepletenost transnacionalnog organizovanog kriminala i terorizma,

Uzajamna zavisnost (korelacija, međuzavisnost) između dva subjekta, posebno vrste delatnosti koje preduzimaju radi ostvarivanja podudarnih ili suprotstavljenih ciljeva, može da bude pozitivna (proizilazi iz očekivanja povezanih sa zajedničkim dobrobitima) ili ne-

\footnotetext{
${ }^{22}$ Londonska deklaracija od 25. novembra 2002. godine o suzbijanju organizovanog kriminala u jugoistočnoj Evropi: „Vladavina zakona jeste temelj demokratije, prosperiteta i dugoročne stabilnosti. Organizovani kriminal sve to ugrožava. To je neprijatelj koga moramo pobediti da ne bi on nas pobedio". - Rory Field (pravni savetnik za organizovani kriminal, OEBS, Beograd): „Posledice organizovanog kriminala na ljudsku bezbednost u Srbiji“, Ljudska bezbednost, Centar za istraživanje ljudske bezbednosti, Beograd, II/2, 2004, str. 145.

${ }^{23}$ Fatić, A.: „Bezbednosni identitet“, Revija za bezbednost, Centar za bezbednosne studije, Beograd, 4, 2009, str. 15.
} 
gativna (proizilazi iz uzajamnih povlačenja i uzajamnih poricanja), simetrična (odvija se pod jednakim uslovima) ili asimetrična (odvija se pod nejednakim uslovima). Kombinovanje ova dva kriterijuma u kontekstu korelacije između nacionalne bezbednosti i transnacionalnog organizovanog kriminala, može da dovede do sledećih suženijih pojmova: pozitivna asimetrična korelacija (prioritetno izražava preventivnu efikasnost sistema nacionalne bezbednosti države u zaštiti nacionalnih interesa od transnacionalnog organizovanog kriminala), negativna asimetrična korelacija (prioritetno izražava represivnu efikasnost sistema nacionalne bezbednosti države u zaštiti nacionalnih vrednosti od transnacionalnog organizovanog kriminala) i negativna simetrična korelacija (uglavnom svojstvena nefunkcionalnim, tzv. „propalim“ državama, a izražava skoro podjednaku moć nosilaca organizovanog kriminala i sistema nacionalne bezbednosti države).

Osnovna funkcija sistema nacionalne bezbednosti države sastoji se u registrovanju opasnosti po bezbednost nacionalnih vrednosti i obezbeđivanju njihove optimalne zaštite. Saglasno oceni da transnacionalni organizovani kriminal predstavlja najopasnija nekonvencionalna pretnja nacionalnim vrednostima države, to ukazuje na potrebu da sistem nacionalne bezbednosti ima presudnu ulogu u određivanju vrste korelacije između nacionalne bezbednosti i transnacionalnog organizovanog kriminala. Radi potvrđivanja dotične potrebe, postavićemo ovakvu formulu: transnacionalni organizovani kriminalni kolektivitet (ciljevi + strategija = profit i/ili moć) - sistem nacionalne bezbednosti (nadležnosti + /ne/odgovornost + /ne/adekvatna kontrola) = pozitivna asimetrična, negativna asimetrična ili negativna simetrična korelacija.

Reč je o nekonvencionalnom sukobu (bojište boje tigrove kože) između dva subjekta - transnacionalni organizovani kolektivitet i nacionalna država, čija je moć asimetrična u korist države. Međutim, transnacionalni organizovani kriminalni kolektivitet teži uspostavljanju odnosa simetrične moći, sa krajnjim ciljem da svoju moć izdigne iznad državne moći. Takav ambiciozan cilj pokušava da ostvari protivzakonitim sticanjem dobiti i/ili moći, sticanjem imovinske koristi i njenog uvećanja, naravno, i njenog legalizovanja. Reč je složenom neuobičajenom dugoročnom procesu koji obiluje račvanjem osnovnog cilja na etapne potciljeve, uz mogućnost da uspešno ostvarivanje nekog potcilja utiče na delimično ili potpuno redefinisanje osnovnog cilja (npr., da se neideološki/materijalni transformiše u politički).

Celokupno delovanje kriminalnog kolektiviteta predstavlja vršenje teških krivičnih dela (čine ih sa umišljajem) radi sticanja imovinske koristi, kojima uzrokuju ogromnu štetu državi. Svoju uspešnost bazira na ofanzivnoj strategiji, čija suština je u onemogućavanju primene unutrašnjeg (nacionalnog) prava. To pretpostavlja neophodnu infiltraciju u sistemu političke vlasti, odnosno korumpiranje pojedinaca ili grupa iz zakonodavne, izvršne i sudske vlasti. Zato, imunitetnost predstavlja najznačajnije obeležje strategije organizovanih kriminalaca, jer opštepoznato je da ukoliko postoji „državna protivkriminalna volja“, nijedna država nije toliko nesposobna da nije u stanju da izađe na kraj sa organizovanim kriminalom čiji su nosioci van sistema političke vlasti. Iskustva iz protivkriminalne prakse ukazuju na to da je nezamislivo dugoročno ispoljavanje i zamah organizovanih kriminalnih delatnosti na određenom prostoru (u određenoj oblasti društvenog života), ukoliko u njima ne učestvuju službena lica određene države. Budući da je kopneni prostor planete Zemlja pod suverenom vlašću 192 države, a međunarodni vazdušni i vodeni prostor predstavlja samo tranzitna mogućnost za delovanje transnacionalnih organizovanih ko- 
lektiviteta, ta činjenica ukazuje na presudnu ulogu (pre svega, odgovornost svojim građanima) nacionalne države u borbi protiv ovog podmuklog neprijatelja. Naime, njegovi pripadnici i strukturni elementi stalno su ili povremeno razmešteni i čine teška krivična dela na teritoriji jedne, dve ili više država.

Ukupno delovanje transnacionalnih organizovanih kriminalaca može se sintetizovati u jednom efektivnom obeležju, koje označava postignute rezultate u određenom vremenskom periodu (npr., kalendarska godina), a to su profit i/ili moć. Dotični rezultat određuje karakter odnosa između organizovanog kriminala i nacionalne bezbednosti države. Ukoliko su rezultati (šteta naneta državi) transnacionalnih kriminalaca minimalni, reč je o adekvatnoj nacionalnoj bezbednosti države, odnosno pozitivnoj asimetričnoj korelaciji. U slučaju da su rezultati kriminalaca rekspektabilni primenom samo jedne vrste ugrožavajuće delatnosti (npr. narko-kriminal), to ukazuje na rovitu nacionalnu bezbednost države, odnosno negativnu asimetričnu korelaciju. Eventualni ishod da su rezultati kriminalaca maksimalni, primenom jedne ili više vrsta ugrožavajućih delatnosti, podrazumeva neadekvatnu nacionalnu bezbednost države, odnosno negativnu simetričnu korelaciju. Ukoliko se takvo nepovoljno stanje nacionalne bezbednosti održava u dužem vremenskom periodu, izgledna je mogućnost da transnacionalni kriminalci nadjačaju državu ili budu uzrok destabilizacije pojedinih ili svih oblasti društvenog života. Radi se o pouzdanom saznanju o tome da ključno „neideološko, vanpolitičko opredeljenje" (profit) transnacionalnih kriminalaca isključuje lojalnost prema nekom političkom subjektu ili sistemu. Međutim, po meri narastanja njihove finansijske moći, iskrsavaju političke ambicije, za čije ostvarivanje ne prezaju od makijavelističkog načela „za ostvarivanje cilja ne biraju se sredstva“. Stoga, masovnim korumpiranjem osoba iz sistema političke vlasti, nastoje da uspostave kameleonsku kriminalnu „paralelnu“ vlast, kompromituju legalno tržište i nacionalnu privredu i imobilišu ključne državne institucije, uključujući i mogućnost da naglašeno primenjuju nasilne oblike delovanja, među kojima je karakterističan teroristički. U tom kontekstu, definicija korupcije bi glasila: korupcija je konstantan bezbednosni izazov svake države, a ukoliko ne bude sprečavana, izgledno je njeno preoblikovanje u najveću bezbednosnu pretnju državi.

\section{Odgovornost sistema nacionalne bezbednosti u ostvarivanju nadležnosti}

Nepobitna je istina da oblik koleracije između transnacionalnog organizovanog kriminala (nekonvencionalna agresija) i nacionalne bezbednosti određene države ne zavisi od agresorove volje, već od političke protivkriminalne volje države, koju njen vrhovni menadžment pokazuje posredstvom sistema nacionalne bezbednosti. Stoga, eventualno marginalizovanje ove činjenice, a nije zanemarljiv broj država savremenog sveta koje su sklone tome, predstavlja veliku (najveću) pogodnost za napredovanje tog specifičnog agresora i stvaranja utiska o njegovoj „neuništivosti“. U kompleksu mera koje sistem nacionalne bezbednosti preduzima radi optimalne zaštite nacionalnih vrednosti matične države od dotične nekonvencionalne agresije, nesumnjivo, najveći efekat mogu imati: preventivna operativno-obaveštajna mera, kojom „ubija“ psihu svakog pripadnika organizovanog kriminalnog kolektiviteta (svestan je da policijsko-bezbednosna komponenta države u toku je teških krivičnih dela koja vrši i dopušta mu da ih čini - nanosi štetu nacional- 
nim vrednostima, samo onoliko vremena, koliko je potrebno da pribavi relevantne dokaze za pokretanje krivičnog gonjenja), sudska mera, koja podrazumeva da izrečena kazna obavezno obuhvata konfiskaciju imovine okrivljenog koju je stekao vršenjem krivičnog dela organizovanog kriminala i ekstradiciona mera, kojom se otklanja mogućnost da izvršilac krivičnog dela, boravkom u drugoj državi, izbegne kaznu. Pomenute mere treba da imaju najsnažniji odvraćajući uticaj na potencijalne i aktivne nosioce organizovanog kriminala. Prva mera ruši pretpostavku kod pripadnika organizovanog kriminalnog kolektiviteta da neće biti otkriveno njegovo protivzakonito delovanje, druga mera ga upozorava da ne može da izbegne oduzimanje protivpravno stečene dobiti, a treća mera, svodi na minimum njegovo uverenje da može izbeći kaznu bekstvom u drugoj državi.

Kontinualno održavanje pozitivne asimetrične korelacije i povremeno ispoljavanje negativne asimetrične korelacije između transnacionalnih organizovanih kolektiviteta i države koju napadaju, iziskuje da njen sistem nacionalne bezbednosti države odgovorno i dosledno ostvaruje svoje nadležnosti. To podrazumeva adekvatno pokazivanje (upotreba) nacionalne moći (zakonito, beskompromisno, neprekidno, stručno, profesionalno, efektivno i efikasno) u procesu zaštite nacionalnih vrednosti od ugrožavajućih delatnosti transnacionalnih organizovanih kriminalnih kolektiviteta.

Ustav države propisuje osnovne nadležnosti ${ }^{24}$ sistema nacionalne bezbednosti u zaštiti nacionalnih vrednosti od svih ugrožavajućih delatnosti (i od organizovanog kriminala), a koje su zakonima i podzakonskim propisima donetih na osnovu njih, konkretnije pravno razrađene. Iz činjenice da je parlament (skupština) zakonodavni organ vlasti, proizilazi i njegova nadležnost donošenja zakona, a to znači i zakona kojima se uređuju društveni odnosi u oblasti zaštite nacionalnih vrednosti od organizovanog kriminala. U okviru svoje ustavom definisane nadležnosti, parlament takođe vrši kontrolu nad radom sistema nacionalne bezbednosti, čiji strukturni elementi - upravljački (vrhovni menadžment države) i operativni (bezbednosne i obaveštajne službe, policija, carinska služba, pravosuđe...) su joj neposredno odgovorni za vršenje funkcija u zaštiti države i društva od organizovanog kriminala.

Nadležnosti svakog elementa (podsistema, subjekta, snaga) sistema nacionalne bezbednosti formulisane su u posebnom zakonu, ${ }^{25}$ koji načelno sadrži sledeće celine: namena i mesto delovanja; poslovi i ovlašćenja; organizacijska struktura i rukovođenje; položaj, prava, obaveze i odgovornosti pripadnika elementa (organizacijska celina, subjekt, organ, institucija); kontrola nad dotičnim elementom; sredstva za delovanje dotičnog elementa; i saradnja sa drugim organizacijskim elementima sistema nacionalne bezbednosti i drugim državnim i društvenim strukturama. Nadležnosti sistema nacionalne bezbednosti predstavljaju svojevrstan izraz unutrašnje podele rada, diferencijacije i specijalizacije njegovih snaga, izraz i uslov njegovog funkcionisanja. Naime, one omogućavaju da svaka vrsta snaga ima i zna koje delatnosti može da vrši, na koji način i pod kojim uslovima.

24 „Nadležnost (kompetencija) je 1) utvrđeni okvir vršenja vlasti nekog organa u sklopu jedne organizacije, 2) skup konkretnih prava i dužnosti svih organa jedne organizacije ili zajednice (npr., "nadležnost države“, 3) osnov za ovlašćenja i njihov izraz i skup“. - Mala politička enciklopedija, Savremena administracija, Beograd, 1966, str. 702.

${ }^{25} \mathrm{Na}$ primer, zakon o sistemu nacionalne bezbednosti, zakon o nadležnosti državnih organa u zaštiti nacionalnih vrednosti od nekonvencionalnih ugrožavajućih delatnosti, zakon o policiji, zakon o krivičnom postupku, zakon o programu zaštite svedoka u krivičnom postupku itd. 
Nadležnost je u istoj meri ovlašćenje i obaveza. Nosilac nadležnosti svoja ovlašćenja mora vršiti istovremeno i jednako kao dužnost, on ne može samovoljno odlučivati da li će je vršiti ili ne. Regulisanje nadležnosti pomoću pravnih normi usmereno je na to da se postigne što preciznije razgraničenje i međusobna koordinacija svih elemenata sistema nacionalne bezbednosti u borbi protiv organizovanog kriminala. Nadležnost pokazuje kvantitet i kvalitet moći, naravno i očekivani doprinos sistema nacionalne bezbednosti u zaštiti nacionalnih vrednosti od transnacionalnog organizovanog kriminala.

Pripadnici i sastavi sistema nacionalne bezbednosti moraju štititi nacionalne vrednosti od organizovanih kriminalaca rukovođeni opštem (državnom) a ne svom privatnom interesu. Svako odstupanje od toga (neovlašćeno delovanje - „prekoračenje nadležnosti“ ili korišćenje izvan ciljeva - „zloupotreba nadležnosti") predstavlja povreda nadležnosti, koja podleže odgovornosti. ${ }^{26}$ Saznanje o tome da od postojanja ili nepostojanja odgovornosti zavisi karakter i oblik jednog političkog sistema, rezultovalo je tome da politika ustanovi osnovne (klasične) institucionalne oblike političke odgovornosti: 1) predstavnička odgovornost, 1) odgovornost šefa države, 3) ministarska odgovornost, 4) političko-upravna i slične odgovornosti, 5) međunarodna odgovornost države.

Svaka prava politička odgovornost je istovremeno i pravna. To znači da nema realne političke odgovornosti bez sankcija, a one su po pravilu predviđene ustavom i zakonom. To opet ne znači da su to jedine i bitne garancije i osnovi odgovornosti, jer pravi odnos odgovornosti je u čoveku i istovremeno u društvenim odnosima. Međutim, svako društvo stvara svoju odbranu u vidu negativne, čiste pravne odgovornosti. Pitanje odgovornosti u pravu postavlja se onda kada subjekt neke pravne obaveze prekrši tu obavezu, izraženu kroz dispoziciju pravne norme. ${ }^{27}$ Kršenjem propisane obaveze ovaj subjekt ulazi u novi pravni odnos sa državom koja je propisala takvu obavezu. U tom novom pravnom odnosu država je ovlašćena, odnosno ima pravo i dužnost, da prema prekršiocu norme (dispozicije) preduzme određene prinudne mere, tj. sankcije, koje moraju biti propisane. Nasuprot ovakvog ovlašćenja države, postoji obaveza prekršioca da se podvrgne izrečenim sankcijama. Prema tome, sankcije u pravu moraju da budu ne samo propisane, već i primenjivane od strane države (njenih nadležnih organa), jer se na taj način obezbeđuje funkcionisanje pravnog poretka (koji čine norme i postupanje po njima). U zavisnosti od društvenih vrednosti, odnosno od značaja društvenih odnosa koji se uređuju i štite pravom, vrši se stepenovanje pravne odgovornosti, pa se tako može govoriti o: krivičnoj, prekršajnoj i disciplinskoj odgovornosti. Svakako da je krivična odgovornost najteži oblik odgovornosti jer ona nastaje kada se prekrše norme kojima se uređuju i štite najznačajnija društvena dobra (vrednosti) i interesi. Saglasno ovakvim oblicima pravne odgovornosti, vrši se i klasifikacija sankcija, tako da se može govoriti o: krivičnim, prekršajnim i disciplinskim sankcijama.

Razmotrene činjenice predstavljaju dobar okvir za ustanovljavanje mogućeg odnosa između nacionalne bezbednosti države i transnacionalnog organizovanog kriminala. $U$ stvari, reč je o složenom dvostranom tajnovitom procesu koji odražava suprotstavljenost ciljeva, strategija i taktika nacionalne države i nosilaca transnacionalnog organizovanog

\footnotetext{
${ }^{26}$ „Odgovornost je pojam koji ima mnoga značenja: a) postojanje ili stanje podnošenja računa za određeni akt ili ponašanje ili propuštanje; b) predmet prema kome ili za koji je neko odgovoran odnosno obavezan da podnosi račun i time istovremeno poverenje ili skup prava i dužnosti;...e) podnošenje posledica u skladu s pravom ili moralom za odgovarajuće akte i ponašanja..... - Mala politička enciklopedija, isto, str. 757.

${ }^{27}$ Vučinić, Z.: Pravo narodne odbrane, Fakultet odbrane i zaštite Univerziteta u Beogradu, 2000, str. 126.
} 
kriminala. Krajnji (zamišljen) rezultat aktera tog asimetričnog procesa je uspostavljanje realnog stanja - nacionalna bezbednost za državu, a kriminalno tržište za personalnog transnacionalnog organizovanog kriminalnog kolektiviteta. Svaki akter upravlja se saznanjem da dotično stanje bude najpovoljnije (optimalno) za njega. U tu svrhu, primenjuje odgovarajuću strategiju (pokazuje sopstvenu moć) koja rezultuje tome da uspešnost jednog od njih u uspostavljanju, održavanju i unapređenju optimalnog stanja, označava neuspešnost drugog aktera. Imajući na umu trajne nacionalne ciljeve države (opstanak i održivi razvoj), naravno, i moć za njihovo ostvarivanje, koja, neuporedivo je veća od moći nosilaca transnacionalnog organizovanog kriminala, zaključak je jednostavan: realno je da nacionalnu bezbednost države karakteriše optimalnost u zaštiti nacionalnih vrednosti od tog specifičnog agresora. Nasuprot tome, relevantna saznanja o rasprostranjenosti transnacionalnog organizovanog kriminala u svetu sistematski opovrgavaju dotični zaključak. Zašto je to tako, ako je opšte poznato da svaka država je zaokupljena dešifrovanjem pomenute oprečnosti? U traganju za odgovorom na to pitanje, smatramo da nauka može imati zapažen doprinos, pre svega, obuhvatom relacije nacionalna bezbednost države - karakteristični oblici transnacionalnog organizovanog kriminala.

Uobičajeno je da država normativno-teorijski definiše transnacionalni organizovani kriminal kao izazov i pretnja nacionalnoj bezbednosti. Pri tome, ima u vidu rizičnost procesa odlučivanja i realizacija odluka radi zaštite nacionalnih vrednosti od organizovanog kriminala. Posebno ima u vidu višefaznost kao važno obeležje bilo kog oblika organizovanog kriminala. To, čak, u slučaju kada ga čine samo dve faze: prva, tzv. proizvodna, u kojoj njegovi akteri činjenjem teških krivičnih dela stiču profit i druga, korupciona, koja u najvećoj mogućoj meri doprinosi održavanju i eskalaciji organizovanog kriminala, između ostalog, zato što je neposredno ili posredno skopčana sa legalizacijom nezakonito stečenog profita „pranjem novca“. Izgledna mogućnost (opasnost) da bar jedna od faza organizovanog kriminala bude realizovana na teritoriji određene države (bezbednosni izazov), ukazuje na njegovo neminovno preoblikovanje u bezbednosnu pretnju ( ugrožavanje bezbednosti najmanje jedne nacionalne vrednosti, dakle, njene nacionalne bezbednosti). To znači da ukoliko izostane pravovremen bezbednosno-profesionalni odgovor sistema nacionalne bezbednosti države u zaštiti nacionalnih vrednosti od transnacionalnog organizovanog kriminala, koji je u nekakvom dosluhu sa domaćim kriminalnim grupama, stvaraju se uslovi za još agresivnije urušavanje njene nacionalne bezbednosti.

Saznanje o postojanju i uspešnom delovanju brojnih i raznovrsnih transnacionalnih organizovanih kolektiviteta ${ }^{28}$ u svetu treba da upozori svaku državu na to da ovaj „podzemni“ agresor predstavlja bezbednosni izazov (moguća opasnost) njenoj nacionalnoj bezbednosti. Reč je o nelagodnom saznanju koje iziskuje realno procenjivanje potencijalne opasnosti (bezbednosni izazov) radi ustanovljavanja mogućnosti njenog eventualnog preoblikovana u bezbednosnu pretnju nacionalnoj bezbednosti. Nacionalna bezbednosna procena ${ }^{29}$ odre-

\footnotetext{
${ }^{28}$ „Najpoznatije transnacionalne kriminalne organizacije su Italijanska mafija, Kolumbijski narko-karteli, Japanske jakuze, Kineske trijade, Ruska i Američka mafija. Pored njih veoma značajnu ulogu imaju Nigerijska mafija, Meksički narko-karteli, Albanska mafija... i druge kriminalne organizacije“. - Radović, N.: „Transnacionalne kriminalne organizacije“, Organizovani kriminalitet - stanje i mere zaštite (zbornik), Policijska akademija Beograd, 2005, str. 390.

${ }^{29}$ Nacionalna bezbednosna procena predstavlja misaono-procesni deskriptivno-objašnjavajući obuhvat uzročnoposledičnih veza između izazova, pretnji i rizika radi ustanovljavanja njihovog posebnog i sintetizovanog uticaja na nacionalnu bezbednost države. Zasnovana je na relevantnim obaveštajnim podacima o objektivnim uslovima i činiocima i subjektivnim okolnostima, a izrađuje se redovno (periodično), prema potrebi i vanredno.
} 
đene države predstavlja poseban oblik objašnjenja opasnosti od transnacionalnog organizovanog kriminala po njenu nacionalnu bezbednost. U opštem smislu, obuhvata uporedno posmatranje i utvrđivanje (1) uzroka njegove prekogranične ekspanzije i motiva koji pokreću njegove nosioce da napadaju njen sistem vrednosti, (2) personalna identifikacija transnacionalnog(-ih) organizovanog(-ih) kolektiviteta, njegovu moć, posebno kako je upotrebljava ili može upotrebiti radi proizvođenja negativnih promena (štetu) nacionalnim vrednostima, odnosno nacionalnoj bezbednosti i (3) sopstvena moć i sposobnost da otkloni opasnost po nacionalnu bezbednost. U posebnom smislu, obuhvata analiziranje: 1) učinilaca krivičnih dela organizovanog kriminala, 2) mesta vršenja krivičnih dela, 3) vremena vršenja krivičnih dela, 4) načina i sredstava korišćenih u vršenju krivičnih dela, 5) objekata napada (nacionalne vrednosti) učinilaca krivičnih dela, 6) eventualnih propuštanja sistema nacionalne bezbednosti u zaštiti nacionalnih vrednosti od organizovanog kriminala i 7) prognoziranje ispoljavanja transnacionalnog organizovanog kriminala.

Zaključci iz nacionalne bezbednosne procene predstavljaju osnovu za kvalitetno odlučivanje vrhovnog menadžmenta države i preventivno-represivno angažovanje sistema nacionalne bezbednosti radi onemogućavanja transnacionalnih organizovanih kriminalnih kolektiviteta da omalovaže i destabilizuju nacionalnu bezbednost matične države. Najzad, treba imati na umu vrhunski značaj kontrolne funkcije celokupne angažovanosti sistema nacionalne bezbednosti. lako, kontrola dolazi do najvećeg izražaja u praktičnoj sferi njegovog funkcionisanja, njena uloga je podjednako važna u normativnoj i teorijskoj sferi zaštite od transnacionalnog organizovanog kriminala. Naime, kontinualno neposredno suočavanje snaga sistema nacionalne bezbednosti sa nosiocima organizovanog kriminala, pored ostalog, registruje (otkriva) eventualna propuštanja u normativnoj i teorijskoj sferi koja ograničavaju njihovo još efikasnije angažovanje na zaštiti nacionalnih vrednosti od te opasnosti. To pokreće zakonodavnu vlast da ažurira postojeću normativu, prema potrebi, usvaja nove zakone i sl. Zato, eventualno zanemarivanje (neoprezno previđanje) značaja kontrolne funkcije, posebno ako je uzrok tome politička korupcija, biće ogromne štetne posledice po nacionalnu bezbednost države. Radi potpunijeg shvatanja konstatovanih činjenica, problematizujemo narko-kriminal, kao jedan od karakterističnih oblika transnacionalnog organizovanog kriminala.

\section{Neka obeležja korelacije između narko-kriminala i nacionalne bezbednosti}

Narko-kriminal predstavlja jedan od postojanih karakterističnih oblika transnacionalnog organizovanog kriminala u savremenom svetu i izražen oblik ugrožavanja nacionalne bezbednosti države. To potvrđuju relevantna saznanja o preovlađujem broju država u svetu, u kojima postoji negativna asimetrična korelacija između narko-kriminala i nacionalne bezbednosti, a evidentni su i slučajevi gde je povremeno ili kontinualno prisutna negativna simetrična korelacija. ${ }^{30} \mathrm{~S}$ tim u vezi, iskrsava logično pitanje: zašto ne preovlađuje pozitivna asime-

\footnotetext{
${ }^{30}$ Predsednik Meksika Felipe Kalderon pokrenuo je opsežnu kampanju protiv trgovine narkoticima krajem 2006. godine, jer su narko-kriminal u toj zemlji karakterisali: brojni nosioci (više narko-kartela) čija je brojčanost (više desetina hiljada članova) veoma rekspektabilna, skoro „perfektna“ organizovanost, adekvatna naoružanost (zaplenjeno 84.000 komada raznog oružja), prilična infiltriranost u sistemu političke vlasti, agresivna i sistematska primena fizičkog nasilja protiv osoba i
} 
trična korelacija (preventivna efikasnost u zaštiti nacionalnih vrednosti od narko-kriminala)? Neki autoriteti će odsustvo ovakve korelacije „obrazložiti“ činjenicom da ne postoji (nije moguće obezbediti) apsolutnu bezbednost bilo koje štićene vrednosti, drugi će isticati nedovoljnu saradnju država u sprečavanju i suzbijanju narko-kriminala, treći će registrovati neopreznost (nesnalažljivost) personalne države u suočavanju sa problemom narko-kriminala, a biće prava retkost da neko identifikuje korupciju kao ključnog uzroka održavanja i „,napredovanja" narko-kriminala, iako je potpuno jasno da bez učešća koruptivnih vladinih službenika u narko-kriminalu, nezamislivo je njegovo dugoročno ispoljavanje u bilo kojoj državi. Na pomenute konstatacije se osvrćemo nakon što problematizujemo osnovne činjenice o narko-kriminalu kao „neotklonjivog“ oblika ugrožavanja nacionalne bezbednosti države.

Narko-kriminal odražava dve strane problema koji predstavlja droga: „tehnička (mehanička) strana, koja je u vezi sa operacijama proizvodnje, prerade, prodaje i pranje novca i (2) kriminalna strana, koja je u vezi sa ilegalnim učesnicima, njihovim terorističkim aktivnostima, kao što su otmice, iznude, ubistva i ucene, i njihovim uticajem na državu“. ${ }^{31}$ Inače, obe strane problema uglavnom imaju transnacionalna obeležja.

Osnovne faze narko-kriminala (proizvodna, transportna, velikoprodajna i maloprodajna) uglavnom sprovode se na teritoriji više država ${ }^{32}$ i predstavljaju protivzakonite radnje za koje je počiniocima predviđena adekvatna kazna. Nosioci (organizatori i neposredni realizatori) pomenutih faza najčešće su više od jednog organizovanih kriminalnih kolektiviteta, ${ }^{33}$ koji, rukovođeni ključnim motivom - novac, odnosno što veći profit - međusobno uspešno sarađuju. Oni, zabranjenom robom (drogom), snabdevaju ilegalno tržište, koje obuhvata proizvodnju, prodaju i potrošnju droge, a celokupnost dotičnog ilegalnog procesa, obavezno podrazumeva primenu najznačajnije faze svakog oblika organizovanog kriminala - „pranje prljavog novca“. Takvom angažovanošću svesno se izlažu riziku (da budu otkriveni i sankcionisani, jer promet droge je strogo regulisan u većini država i od strane međunarodnog prava). Međutim, imaju velike prednosti (izbegavaju plaćanje poreza, koriste nasilje i zastrašivanje svojih konkurenata, korumpiraju službena lica, „oprani prljavi novac“ plasiraju u legalno tržište..., a neki od njih, deo stečenog profita upotrebljavaju za finansiranje terorizma) u odnosu na legalne poslovne subjekte. U stvari, nosioci narko-kriminala takvom angažovanošću kontinualno neposredno ugrožavaju ljudsku bezbednost $t^{34}$ a posredno ugrožavaju nacionalnu bezbednost države.

kolektiviteta koji ometaju njihovo narko-tržište i transnacionalnost, prioritetno u odnosu na narko-kriminalce u SAD. - N.N.: „Prikaz borbe meksičkih vlasti u 2010. godini protiv narko-kartela“, Politika, Beograd, 18. 1. 2010, str. 5.

${ }^{31}$ Bajbs, P.: „Međunarodni organizovani kriminal i terorizam“, Pogledi, Policijska akademija, Beograd, 2 , 2003, str. 17.

${ }^{32}$ „Srbija je uglavnom tranzitna zemlja za krijumčarenje droga. Njena teritorija pozicionirana je u centru švercerskih puteva duž Balkana. Heroin se švercuje iz Turske preko Bugarske u Srbiju, a zatim dalje ka Zapadnoj Evropi. Manje količine heroina ostaju u zemlji. Kokain obično dolazi iz Južne Amerike u Srbiju preko Španije, Italije, Grčke, dok je poreklo sintetičkih narkotika prvenstveno iz Holandije. Primetno je povećanje broja laboratorija za proizvodnju sintetičkih droga unutar Srbije“. - International Narcotics Control Strategy Report - Volume I Drug and Chemical Control, USA, Bureau for International Narcotics and Law Enforcement Affairs, March 2007, p. 473-475.

${ }^{33}$ Priličan broj istraživača, izučavajući strukturu „industrije droge“ ili narko tržišta, ustanovili su da se u lancu između proizvođača i krajnjih korisnika droge javljaju brojni učesnici, čak do desetak. - Ignjatović, Đ.: Organizovani kriminalitet, drugi deo, Policijska akademija, Beograd, 1998, tr. 72-74.

${ }^{34}$ „Droge su supstance prirodnog ili sintetičkog porekla, čijom se upotrebom mogu stvoriti stanja zavisnosti koja mogu da izazovu oštećenje zdravlja ili da na drugi način ugroze ljudski integritet u fizičkom, psihičkom ili socijalnom smislu“. - Petrović, D.: Neovlašćena proizvodnja i stavljanje u promet opojnih droga, Srpsko udruženje za krivično pravo, Kopaonik, 1999, str. 18. 
Reč je o specifičnom obliku ugrožavanja ljudske bezbednosti, koji, iako ima elemenata samougrožavanja, ne oslobađa državu od odgovornosti da optimalno zaštiti neposrednu žrtvu. Naime, potencijalna (i "gotova“) neposredna žrtva droge (čovek kao jedinka, uglavnom mlađa, često maloletna osoba), pošto postane zavisnik, sarađuje sa trgovcem narkotika, odnosno svesno ga štiti. Njihov „poslovni“ odnos se odvija tajno, zbog čega njegovo sagledavanje (otkrivanje, nadzor i dokumentovanje) zahteva primenu tajnih metoda i sredstava policijsko-bezbednosne komponente sistema nacionalne bezbednosti. Imajući u vidu namenu, organizovanost, opremljenost, osposobljenost i profesionalnost policijsko-bezbednosne komponente radi efikasnog suočavanja sa narko-kriminalom, nisu osnovane tvrdnje o tome da joj je veoma teško da izvršava, ovaj nesumnjivo komplikovan, inače, za nju, uobičajeni zadatak. To, nezavisno od brojnih uslova, uzroka i faktora koji mogu da je sputavaju u uspešnom izvršenju tog zadatka, koje, mogu se razvrstati u tri grupe,. Za njihovo valjano razumevanje neophodno je imati u vidu pomenutu formulu o sistemu nacionalne bezbednosti (nadležnosti + /ne/odgovornost +/ne/adekvatna kontrola = pozitivna asimetrična korelacija).

Prvu (tzv. eksternu) grupu, pre svega, mogu činiti jedno od sledećih ograničenja: tolerantna nacionalna protivkriminalna politika čiju okosnicu predstavlja nepostojanje adekvatne volje vrhovnog menadžmenta države za odsudnu odbranu nacionalnih vrednosti od narko-kriminala (politička korupcija ${ }^{35}$ ), ozbiljna propuštanja u zakonodavnoj sferi koja se sastoje u neadekvatnim ovlašćenjima policijsko-bezbednosne komponente da sprečava i suzbija narko-kriminal (uzroci: neopreznost, neznanje ili koruptivnost zakonodavne vlasti), i neadekvatno upravljanje sistemom nacionalne bezbednosti - u jednoj ili svih faza (odlučivanje, realizacija, koordinacija, kontrola i korišćenje rezultata) radi optimalne zaštite nacionalnih vrednosti od narko-kriminala. Uzroci druge (tzv. interne) grupe ograničenja najčešće predstavljaju: nesposobnost jedne vrste snaga ili celokupne policijsko-bezbednosne komponente da vodi uspešnu borbu sa nosiocima narko-kriminala (malo verovatan slučaj) i koruptivnost policijsko-bezbednosne komponente (verovatan slučaj). Osnovano ili neosnovano, u opticaju su shvatanja o tome da ukoliko treća grupa (sudska komponenta) profesionalno, u prihvatljivom (objektivnom) vremenskom roku ne realizuje postupak protiv osumnjičenog za narko-kriminal, a pod tim se podrazumeva i obavezno oduzimanje nezakonito stečene dobiti, na taj način može da omalovaži uložene napore i rezultate celokupnog sistema nacionalne bezbednosti.

Prvenstveno zbog toga što narko-kriminal direktno (tajno) ugrožava fizički, ${ }^{36}$ psihički i socijalni integritet čoveka (referentna nacionalna vitalna vrednost) i izaziva (javne) veoma štetne društvene posledice, ${ }^{37}$ jesu činjenice koje ukazuju na najveću moguću odgovornost države u pogledu zaštite svojih građana od narko kriminalaca. Suvišno je isticati da uprkos uslovne dvodelnosti tog zadatka, njegovim uspešnim izvršenjem, višestruko

\footnotetext{
${ }^{35}$ „Politička korupcija podrazumeva loše postupanje političara, štetno za javnost i državu, radi zadovoljavanja ciljeva u vezi sa ličnim karijerizmom ili interesima sebi bliskih ljudi“. - Fatić, A.: „Politička korupcija“, Revija za bezbednost, Centar za bezbednosne studije, Beograd, 12, 2008, str. 29.

${ }^{36}$ Evropski centar za praćenje droga saopštio je da u Evropi u 2014. godini registrovano 6.800 smrtnih slučajeva od predoziranje narkoticima. - Telesković, D.: „Mladi narkomani u EU zamorčići za nove droge ““, Politika, Beograd, 6. 6. 2015, str. 8.

${ }^{37}$ Povodom najave rasprave u Vladi Srbije o Nacrtu nacionalne strategije za borbu protiv droga, saopšteno je da u Srbiji živi oko 100. 000 narkomana. - N.N.: „Nacionalna bitka protiv droge“, Politika, Beograd, 24. 8. 2007, str. 1.
} 
osnažuje sopstvenu nacionalnu bezbednost. Njegovu prvu celinu obuhvata sprečavanje i suzbijanje krivičnih dela narko-kriminalaca (privatna lica i korumpirana službena lica) s ciljem da ih onemogući da plasiraju drogu na kriminalnom tržištu, a druga celina obuhvata borba protiv tzv. kriminaliteta narkomana (mnogi od njih novac za kupovinu droge obezbeđuju tako što čine krivična dela krađe, razbojništva, prostitucija, prosjačenje ili pod dejstvom narkotičkih sredstava na razne načine ugrožavaju fizičku i psihičku bezbednost drugih ljudi). Ovim postaje jasno da ukoliko sistem nacionalne bezbednosti uspešno izvršava prvu celinu zadatka, biće zanemarljiva potreba njegovog angažovanja u realizaciji druge celine zadatka, koja, u stvari, predstavlja tzv. klasičan kriminal.

Dosledna primena nadležnosti i ovlašćenja od strane policijsko-bezbednosne komponente sistema nacionalne bezbednosti, odnosno uspešno izvršenje prve celine zadatka predstavlja velika garancija da će negativna asimetrična korelacija između narko-kriminala i nacionalne bezbednosti „kliziti“ ka pozitivnoj asimetričnoj korelaciji, a eventualno neuspešno izvršenje prve celine zadatka može rezultovati da dotična korelacija bude negativno simetrična. Naime, policijsko-bezbednosna komponenta u neposrednom „borbenom dodiru" sa narko-kriminalcima ima mogućnosti da nakon pribavljenih početnih operativnih podataka o potencijalnom izvršioca krivičnog dela u vezi sa opojnim drogama, zahteva od nadležnog suda odobrenje za primenu posebnih metoda ${ }^{38}$ radi prikupljanja relevantnih saznanja i pokretanje krivične odgovornosti protiv izvršilaca krivičnih dela u vezi sa zloupotrebom opojnih droga. Uspešnost primene posebnih metoda zavisi od stručnosti i profesionalnosti pripadnika i sastava policijsko-bezbednosne komponente. Iskustvena protivkriminalna praksa mnogih država ukazuje na to da dotični kvaliteti, uglavnom, nisu sporni. Sa druge strane, dotična praksa takođe upozorava na prisutnost raznih problema koji ograničavaju i omalovažavaju angažovanost policijsko-bezbednosne komponente, povremeno izraženih čak do nivoa, koji obezvređuje celokupnu angažovanost policijsko-bezbednosne komponente. Reč je, pre svega o zanemarivanju značaja lične i moralne odgovornosti što ima za posledicu urušavanje institucionalne odgovornosti u ostvarivanju adekvatne interne i eksterne kontrole procesa angažovanja sistema nacionalne bezbednosti radi zaštite nacionalnih vrednosti od narko-kriminala.

Zato, može se činjenično tvrditi da izostanak adekvatne kontrole presudno utiče na karakter korelacije (negativna asimetrična ili simetrična) između narko-kriminala i nacionalne bezbednosti. Jer njeno eventualno odsustvo neminovno podstiče potencijalno koruptivne pojedince iz sistema nacionalne bezbednosti da svoju pohlepu stave ispred nacionalnih interesa, odnosno opredele se da je zadovolje neposrednim ili posrednim učešćem u narko-kriminalu. Uključenost službenog lica u sprovođenju bilo kakve narko kriminalne delatnosti, nezavisno od njegovog mesta u hijerarhijskoj lestvici izvršne, zakonodavne ili sudske vlasti predstavlja najopasniji oblik ugrožavanja bezbednosti matične $d r$ žave. Po tom osnovu, samo delimično je održiva teza u opticaju o tome da nema narkokriminala bez uključenosti pojedinih policajaca. Iskustva iz prakse ukazuju da je ispravnija teza da su: 1) veoma ograničene ili minimalne mogućnosti narko-kriminalaca u odre-

\footnotetext{
${ }^{38}$ Uobičajene posebne metode su: prikriveni islednik, svedok saradnik, pružanje simulovane usluge i sklapanje simulovanih pravnih poslova, mera kontrolisane isporuke, nadzor i snimanje telefonskih i drugih razgovora ili komunikacija drugim tehničkim sredstvima i optičko snimanje, kontrola poslovanja određenih lica i privremeno oduzimanje predmeta i imovinske koristi.
} 
đenoj državi ukoliko im na neki način ne povlađuju osobe iz sistema političke vlasti (reč je o varijanti kada su isključivo privatna lica narko-kriminalci); 2) rekspektabilne su mogućnosti narko-kriminalaca ukoliko u narko-kriminalu učestvuju pojedinci iz policijskobezbednosne komponente; 3) maksimalne su mogućnosti narko-kriminalaca ukoliko im pomažu pojedinci ili grupe iz sistema političke vlasti i 4) najveće su mogućnosti narko-kriminalaca kada im pomažu pojedinci iz vrhovnog menadžmenta države.

Nesumnjivo, rezultati naučnog istraživanja aktuelnog narko-kriminala u nekoj državi potvrdili bi hipotezu o tome da je neodrživo njegovo dugoročno opstajanje i/ili eskalacija bez nekakve uključenosti službenih lica. U stvari, upozorili bi na činjenicu o tome da vansistemski (privatni) narko-kriminal, vremenski može da traje onoliko dugo koliko je sistemu nacionalne bezbednosti potrebno vremena da od početnog operativnog podatka proširi saznanja i dokumentuje počinjeno krivično delo, odnosno pokrene krivično gonjenje protiv počinilaca. Realno je pretpostaviti da bi se do sličnih rezultata došlo istraživanjem i drugih oblika transnacionalnog organizovanog kriminala. $U$ tom slučaju, bila bi održiva negativna asimetrična korelacija između nacionalne bezbednosti i narko-kriminala (i drugih oblika organizovanog kriminala), sa tendencijom preoblikovanja u pozitivnu asimetričnu korelaciju.

Saznanje o realnim mogućnostima države da efikasno (optimalno) zaštiti nacionalne vrednosti od narko-kriminala, bez obzira na to da li su njegovi nosioci lokalno ili transnacionalno povezani, treba da bude osnovni orijentir vrhovnom menadžmentu države u procesu rukovođenja sistemom nacionalne bezbednosti. Njegova angažovanost i rezultati u tom kontekstu pretpostavljaju posedovanje kredibilnih osobina (poštenje, patriotizam, odgovornost i sposobnost) čijim sistematskim pokazivanjem upozorava svakog lica, pre svega službena lica, da eventualnim štetnim (amoralnim, neodgovornim, pohlepnim, koruptivnim, kriminalnim, antinacionalnim, iracionalnim, narcisoidnim, nepotičkim, ekstremističkim...) postupanjem, negativno utiče na nacionalnu bezbednost matične države. Naravno, nije dovoljno da samo upozorava. Takođe, neophodno je da ostvaruje uvid (kontrolu) u funkcionisanju sistema nacionalne bezbednosti države radi ustanovljavanja da li se zakonska regulativa i odluke dosledno ostvaruju u praksi. Svrha kontrole jeste registrovanje eventualnih odstupanja u operativnoj praksi (u ovom slučaju, u zaštiti nacionalnih vrednosti od narko-kriminala) i njihovo otklanjanje donošenjem korektivnih odluka i izdavanje naloga za njihovo izvršenje.

\section{Zaključak}

Bezbednost je osnovna funkcija svake države, a ostvaruje je posredstvom sistema nacionalne bezbednosti. Pouzdan pokazatelj o efikasnosti funkcionisanja sistema nacionalne bezbednosti određene države predstavlja njegov rezultat - stanje nacionalne bezbednosti u datom trenutku, koje, kako praksa pokazuje može da bude stabilno, nestabilno ili kritično. Stanje nacionalne bezbednosti određene države, pored ostalog, ukazuje na to da li njenog sistema nacionalne bezbednosti preovladavajuće karakteriše preventivnost (odvraća i sprečava nosioce ugrožavajućih delatnosti da napadnu nacionalne vrednosti) ili represivnost (sa različitom uspešnošću suzbija ugrožavajuće delatnosti odnosno onemogućava njihove nosioce nakon što su ih preduzeli protiv nacionalnih vrednosti matične države). 
Savremenom organizovanom kriminalu su svojstvena mnoga transnacionalna obeležja. Njegova karakteristična odrednica se sastoji u optimalno uspešnoj saradnji između nosilaca lokalnog i globalnog organizovanog kriminala, zasnovana na zajedničkoj koristi. Nosioci lokalnog organizovanog kriminala (na teritoriji jedne države) napadaju svaku nacionalnu vrednost, svaku oblast društvenog života, sve građane matične države. Zbog toga predstavljaju ozbiljnu opasnost (pretnja) njenoj nacionalnoj bezbednosti. Međutim, dotična pretnja postaje još izraženija i teže otklonjivija, ukoliko pojedini oblici organizovanog kriminala (npr., trgovina narkoticima, trgovina ljudima, krijumčarenje ljudi, šverc oružja, krađa putničkih vozila...) preduzimaju u saradnji sa transnacionalnim organizovanim kolektivitetima. To, između ostalog, zbog moguće povezanosti transnacionalnih organizovanih kriminalaca sa stranim obaveštajnim službama, terorističkim, paravojnim i sličnim kolektivitetima.

Višedimenzionalna ekspanzija transnacionalnog organizovanog kriminala kroz osnaživanje postojećih i stvaranja novih tržišta, pre svega zbog koruptivnih vladinih službenika u rekspektabilnom broju država, rezultovalo je tome da su ga funkcionalne (uspešne) države prepoznale kao najopasniju nekonvencionalnu pretnju nacionalnim vrednostima. Analogno tome čine odgovarajuće napore da postojeću negativnu asimetričnu korelaciju između nacionalne bezbednosti i transnacionalnog organizovanog kriminala, preoblikuju u pozitivnu asimetričnu korelaciju. Nasuprot njima, u nefunkcionalnim (bezbednosno protivkriminalno neopreznim) državama, organizovanom kriminalu je postao sastavni deo društva i ne može se više odstraniti. Glavni indikator takvog stanja je totalna korupcija u državnom aparatu na svim nivoima, koja legitimiše negativnu simetričnu korelaciju između nacionalne bezbednosti i transnacionalnog organizovanog kriminala.

Nezavisno od postojeće korelacije između nacionalne bezbednosti određene države i transnacionalno organizovanog kriminala (negativna asimetrična ili simetrična), bilo bi tendenciozno tvrditi da je moguće njegovo potpuno iskorenjivanje u kratkom vremenskom roku. Međutim, osnovano je pretpostaviti da ukoliko sistem nacionalne bezbednosti napadnute države, u realnom vremenskom roku (npr., nekoliko godina) uspe da identifikuje i odstrani pojedince i grupe iz svojih redova povezanih sa domaćim i transnacionalnim organizovanim kriminalnim kolektivitetima, bili bi stvoreni uslovi da u narednom periodu optimalno uspešno štiti svoje nacionalne vrednosti od te opasnosti. U stvari, ukoliko je reč od državi u kojoj je odnos između transnacionalnog organizovanog kriminala i nacionalne bezbednosti bio negativno asimetričan ili simetričan, ima izglede da ga preoblikuje u pozitivno asimetričnog. Ovakvo radikalno suočavanje sa tom gorućem pretnjom nacionalnoj bezbednosti moguće je u parlamentarnim demokratijama (država, u kojima je smenjiva vlast). Naravno, to samo u slučaju, ako politička stranka - pobednik na višestranačkim izborima, iskreno je obećavala biračima da će optimalno suzbiti organizovani kriminal, a za vreme svog mandata (vršenje vlasti) transparentno potvrđuje svoju protivkriminalnu iskrenost, između ostalog, tako što istinito obaveštava javnost o rezultatima borbe protiv organizovanog kriminala (npr., o ukupnom broju onesposobljenih organizovanih kriminalnih kolektiviteta, ukupnom broju njihovih članova lišenih slobode i sudski sankcionisanih, naročito isticanjem broja korumpiranih službenih lica, oduzetoj protivpravno stečenoj imovini...). Na nesreću građana i veliku korist domaćih i transnacionalnih organizovanih kriminalaca, politička elita u 
mnogim državama savremenog sveta, uglavnom, samo deklarativno vodi „žestoku“ borbu sa organizovanim kriminalom i na sličan način sarađuje sa drugim državama na suzbijanju transnacionalnog organizovanog kriminala. Takvo intrigantno lokalno i globalno stanje organizovanog kriminala će nesumnjivo pogodovati njegovim amoralnim i anacionalnim nosiocima da i u doglednoj budućnosti predstavljaju najveća nekonvencionalna pretnja nacionalnoj bezbednosti mnogim državama.

\section{Literatura}

[1] Albanese, S. J.: „The causes of organized crime“, Journal of Contemporary Criminal Justice, Thousand Oaks, No. 4, 2000, pp. 40-423.

[2] Bajagić, M.: Međunarodna bezbednost, Kriminalističko-policijska akademija, Beograd, 2012.

[3] Bajbs, P.: „Međunarodni organizovani kriminal i terorizam“, Pogledi, Policijska akademija, Beograd, 2, 2003, str. 17-28. 1998.

[4] Bošković, M.: Transnacionalni organizovani kriminalitet, Policijska akademija, Beograd,

[5] Bošković, G.: „Organizacija i funkcionisanje kriminalnog tržišta“, Revija za bezbednost, Centar za bezbednosne studije, Beograd, 2, 2008, str. 38 - 42.

[6] Gaćinović, R.: „Klasifikacija bezbednosti“, Nauka, bezbednost, policija, Kriminalističkopolicijska akademija, Beograd, 2, 2012, str. 3-26.

[7] Fatić, A.: „Politička korupcija“, Revija za bezbednost, Centar za bezbednosne studije, Beograd, 12, 2008, str. 29-33.

[8] Fatić, A.: „Bezbednosni identitet“, Revija za bezbednost, Centar za bezbednosne studije, Beograd, 4, 2009, str. 5 -19.

[9] International Narcotics Control Strategy Report - Volume I Drug and Chemical Control, USA, Bureau for International Narcotics and Law Enforcement Affairs, March 2007.

[10] „Konvencija Organizacije ujedinjenih nacija protiv transnacionalnog organizovanog kriminala“, Službeni list SRJ - Međunarodni ugovor, broj 6/2001.

[11] „Krivični zakonik Republike Srbije“, Službeni glasnik RS, br. 58/2004, 85/2005, 88/2005 i $107 / 2005$.

[12] Leffler, M. P.: „National Security“, Journal of American History, No.77, 1990, p. 145. In Baldwin, D.: „The concept of Security“, Review of International Security, Vo. 23, No. 1, 1997, p. 1-24.

[13] Mala politička enciklopedija, Savremena administracija, Beograd, 1966.

[14] Marinković, D.: „Organizovani kriminalitet - izazov krivičnom zakonodavstvu“, Bezbednost, MUP Srbije, 2, 2004, str. $191-208$.

[15] Mijalkovski, M.: Obaveštajne i bezbednosne službe, Univerzitet u Beogradu - Fakultet bezbednosti, Službeni glasnik, Beograd, 2009.

[16] Mijalkovski, M.: „Organizovani kriminal - najopasniji oblik ugrožavanja bezbednosti države“, Revija za bezbednost, Centar za bezbednosne studije, Beograd, 12, 2008, str. 5-16.

[17] Miletić, A.: Nacionalni interes u američkoj teoriji međunarodnih odnosa, Savremena administracija, Beograd, 1978.

[18] Miller, B.: Security: Should it be Redefined? In Bar-Joseph, U. (ed) (2001). Izrael's National Security Towards the 21st Century, Frank Cass, London, 2001.

[19] Naylor T. R.: „A critique of follow-the-money methods in crime control policy“, Crime, Law and Social Change“" London, Vol. 32, 1999. 
[20] Ney, J.S.: Understanding International Conflicts (5th edition), Pearson Seducation, New York, 2005.

[21] Radović., N.: „Transnacionalne kriminalne organizacije“, Organizovani kriminalitet - stanje i mere zaštite (zbornik), Policijska akademija, Beograd, 2005, str. 389 - 407.

[22] Rory, F.: „Posledice organizovanog kriminala na ljudsku bezbednost u Srbiji“, Ljudska bezbednost, Centar za istraživanje ljudske bezbednosti, II/2, 2004, str. 145-150.

[23] Shmalleger, F.: Criminolgy Today, Englewood Cliffs, London, 1996.

[24] Vučinić, Z.: Pravo narodne odbrane, Fakultet odbrane i zaštite Univerziteta u Beogradu, Beograd, 2000.

[25] Weenink W. A.: Crime without frontiers: Crime Pattern Analysis Eastern Europe, 20022003, Netherlands: Korps Landelijke Politiediensten, Driebergen, 2004.

[26] „Zakon o organizaciji nadležnosti državnih organa u suzbijanju organizovanog kriminala“, Službeni glasnik RS, br. 42/2002, 27/2003, 39/2003, 39/2003, 67/2003, 29/2004, 45/2005, 61/2005, 72/2009.

[27] „Zakon o krivičnom postupku“, Službeni list SRJ, br. 70/2001 i Službeni glasnik RS, br. $58 / 2004,85 / 2005,115 / 2005$. 